The Canadian Journal of Higher Education, Vol. XXV-3, 1995

La revue canadienne d'enseignement supérieur, Vol. XXV-3, 1995

\title{
Graduate student supervision policies and procedures: A case study of issues and factors affecting graduate study
}

\section{JANET G. DONALD, ${ }^{*}$ ALENOUSH SAROYAN, ${ }^{*}$ \& D. BRIAN DENISON*}

\begin{abstract}
This study was designed to identify salient issues in supervision across disciplines at a Canadian research university with a history of decentralized administration of graduate programs. Three sets of issues guided the inquiry: (a) the definition of supervision, (b) policies and procedures for supervision, and (c) the resources available for supervision. Although most departments reported having some form of policies and procedures, they did not tend to be explicitly stated or communicated. According to program directors, the two most important factors in the graduate supervision process were the supervisor's knowledge of the research field and his or her availability. There was considerable variability across faculties in the existence of policies and in the importance attached to different factors. Resources also varied greatly across disciplines. One conclusion of the study is that since the process of supervision is complex and occurs within a disciplinary context, much of the effort involved in enhancing the quality of graduate student supervision must be made at the department level. However, a comprehensive definition of graduate student supervision is needed to ensure that, where possible, there is common ground for graduate student supervision policy and practice.
\end{abstract}

* The Centre for University Teaching and Learning, McGill University. This paper is based on research funded by the Social Science and Humanities Research Council of Canada and the Québec Fonds pour la Formation de Chercheurs et l'Aide à la Recherche. 


\section{Résumé}

Cette étude a été conçue de manière à identifier des questions importantes de supervision dans diverses disciplines, dans une université de recherche canadienne ayant des antécédents en matière de décentralisation administrative de programmes d'études supérieures. Trois ensembles de questions ont guidé l'étude: (a) la définition du terme supervision, (b) les politiques et procédures régissant la supervision, et (c) les ressources affectées à la supervision. Si la plupart des départements ont dit disposer de quelconques politiques et procédures, plus rares étaient ceux qui les avaient formulées ou communiquées explicitement. La connaissance du domaine de recherche et la disponibilité du superviseur étaient les deux facteurs les plus importants du processus de supervision. On a constaté des différences considérables entre les facultés pour ce qui a trait à l'existence de politiques et à l'importance attachée à divers facteurs. Le niveau de ressources variait en outre grandement d'une discipline à une autre. L'étude conclut notamment que, le processus de supervision étant complexe et s'inscrivant dans le contexte d'une discipline, une grande partie des efforts déployés afin de relever la qualité de la supervision des étudiants aux niveaux supérieurs doit se faire dans les départements. Toutefois, il y aurait lieu de formuler une définition globale de ce qu'on entend par supervision des étudiants aux niveaux supérieurs afin de s'assurer que la politique et la pratique en matière de supervision des étudiants à ces niveaux reposent dans la mesure du possible sur une base commune.

Supervision plays a critical role in the introduction to and preparation of graduate students for scholarly life (Katz \& Hartnett, 1976; Powles, 1988). In light of its potential impact on attracting, retaining, and graduating students, the supervision process has become an increasingly important topic, particularly at research universities. Reports have shown that constant, thoughtful supervision is a key to successful graduate program completion (Holdaway, 1991). Despite such assertions, since 1968, there has been an increase in the time to complete doctoral degrees which has in turn led to questioning both the output of graduate education and the definition of its content (Tuckman, 1991). Conceptual ambiguity characterizes the definition of graduate student supervision. Some disciplines may define it as a process of aiding the student to become a member of a research team and by extension, a member of the discipline. Others may conceive of supervision more narrowly as setting deadlines to ensure that students complete learning and research tasks. 
One reason that institutions have made little progress in establishing crossdisciplinary consistency in supervision practice is that departments function as gatekeepers or guardians of the disciplines, particularly at entry to the level of acknowledged disciplinary expertise. They may therefore be unwilling to allow standards from outside the discipline to be imposed upon the education of potential members of their own discipline. Moreover, major disciplinary areas differ in the emphasis they place on the kind of assistance to be offered to students and on the relative importance of various aspects of supervision (Holdaway, Deblois, \& Winchester, 1994). A more fundamental problem, however, is the limited understanding of graduate student development. Despite research on time to completion, there are few procedures in place to guide students through the developmental stages they undergo as they progress in their graduate programs.

University policy statements reflect limited comprehension of the supervision process. Accountability procedures in universities tend to conceptualize supervision in terms of general indicators or outcomes of graduate education, for example, the number of graduates completing their degrees within a specified time frame or the number of fellowships received by students. While supervision has some influence on these outcomes, they reveal little about either the process of supervision or the factors determining its effectiveness. At the same time, there is growing suspicion that graduate student supervision is an under-resourced area in the university. Without a sense of the constituent parts of the supervision process, however, it is difficult to put forward logical arguments for the kinds of resources needed for supervision. These issues - ambiguity in the definition of supervision, policies not specifically attuned to the supervision process, and limited resources-constrain the efficacy of universities in providing quality supervision and, therefore, assuring the development of the future professoriate.

If the quality of graduate student supervision is to be improved in our universities, we need to know more about policies and related practices and the factors that are considered important in graduate student supervision. The purpose of this study was to identify salient issues in graduate student supervision across disciplines by examining the state of current policies and procedures at a Canadian research university with a history of decentralized administration of graduate programs. Although policies for graduate student supervision existed in the university, little was known about which policies and procedures were recognized and adhered to by various faculties and departments and to what extent factors affecting graduate study were considered important. The first step in this process was to review the literature for available definitions of supervision. 


\section{Definition of graduate student supervision}

Supervision is widely recognized as being complex and multidimensional. Often no distinction is made between research supervision, advising, and field supervision. In one attempt to define it, graduate student supervision was described as a blend of academic expertise and the skillful management of personal and professional relations (Ballard \& Clanchy, 1993). The American Council of Graduate Schools in Research student and supervisor (1990) suggests that there are two major aspects to the supervision of graduate research students:

The first and more important has to do with creativity and involves the ability to select problems, to stimulate and enthuse students, and to provide a steady stream of ideas. The second aspect is concerned with the mechanics of ensuring that the student makes good progress. (p. 5)

The Council of Graduate Schools (1990) takes the perspective that because the intellectual and interpersonal aspects of graduate studies are so dependent on the characteristics of the persons involved, it is extremely difficult to provide any general guidance. Consequently, its recommendations and guidelines focus on the mechanics or procedures of supervision, as do the recommendations of the Commission of Inquiry on Canadian University Education (Smith, 1991). For example, the Commission specified required reporting on the status of each graduate student and on the schedule for completion of studies.

Recent attempts to conceptualize graduate student supervision have tended to emphasize the interpersonal or socialization roles of supervisors as well as being an advocate and role model both within the department and the profession (Winston \& Polkosnik, 1984). These attempts reflect the understanding that although expertise in one's field of specialization and active involvement in research are prerequisites for a supervisor, they do not guarantee good supervisory practice (Powles, 1993). Students expect their supervisors to have knowledge and the ability to supervise in a particular area of research but also want them to be reasonable, serious, supportive of their work in good times and bad, and approachable (Moses, 1985). Moreover, supervisors are expected to take the lead in establishing relations with their students so that their knowledge and skills are readily accessible to students (Ballard \& Clanchy, 1993). One author has asserted that personal support is the most important dimension of supervision (Salmon, 1992). These interpersonal qualities, neither easily prescribed nor proceduralized, seem to be gaining importance in the supervision literature.

Conceptualization of the roles and functions of graduate supervision becomes more complex in light of the stages of development graduate students 
go through during graduate studies (Bargar \& Mayo-Chamberlain, 1983; Beeler, 1991; Tinto, 1993; Winston \& Polkosnik, 1984). Research suggests that most doctoral students progress through four stages: program entry, program building, general or comprehensive examinations, and dissertation (Bargar \& Mayo-Chamberlain, 1983). The dissertation stage consists of four substages of developing the topic, doing the research, writing the thesis, and defending it. A fifth stage, separation and job placement, has been identified by Winston and Polkosnik (1984). At each stage, graduate students are likely to need different forms of guidance. During the initial weeks, for example, entering students (particularly at the master's level) are likely to require a high degree of structure and direction from their supervisors (Winston \& Polkosnik, 1984). Students also need particular guidance on when to stop data collection and analysis, when to start drafting the thesis, and how to structure it (Moses, 1992).

The various needs of students on the one hand, and the diverse academic responsibilities of professors on the other, make the characterization of good supervision even more elusive. The task is further complicated by the varied range of resources that departments and universities provide in support of supervision. For example, some departments accept only those students whom they can support financially through research or teaching assistantships. Many graduate programs list courses on research methods or thesis preparation; these could be expected to provide considerable guidance to students in the development of their dissertations. Departmental organization that structures the environment of the student in this manner allows supervisors to attend to more specific issues of supervision.

\section{Supervision Policies}

Even though the supervision process may not be well understood, both general and specific policies relating to graduate student supervision are found in university documents. Generally speaking, foremost among institutional concerns is ensuring that students graduate within a reasonable period of time (Bowen \& Rudenstine, 1992; Moses, 1992; Powles, 1988; Sheridan \& Pyke, 1994). University-wide policies are, however, often constrained since decisionmaking authority tends to rest in the departments or faculties which claim varied disciplinary needs and cultures.

In the university examined in this case study, documented policies for procedures to be followed were found in reports produced by the Graduate Faculty Council (1986) and in the Students' Handbook on Rights and Responsibilities. The Graduate Faculty Council (1986) document, Time to Complete Graduate Studies, made specific suggestions about departments' responsibilities concerning 
student progress, including ensuring regular meetings and an annual assessment of student progress, copied to the student. In this document, it was stated that graduate studies require full-time status. In addition to these policies, a Senateapproved report on university-wide priorities (1991) provided extensive recommendations about standards, procedures for graduate studies, and supervision quality and efficacy. Graduate student supervision was to include guidance in the choice of courses and seminars, encouragement to publish and to participate in national and international conferences, and the provision of a fund to support graduate students in these activities. Specific procedures were recommended to establish clear schedules and formal supervisory committees. However, since many of the responsibilities and procedures for supervision issues were department-based, the extent to which university policies were deemed appropriate or were consistent with practice in departments was not known.

\section{Resource Base for Supervision}

A further stumbling block in ensuring adequate supervision is the provision of resources and procedures within a given department. While professors are increasingly recognized by university awards for exceptional supervision (for example, in Graduate Faculty teaching awards), departments have placed little emphasis on the value of supervision for workload credit. A related mediating variable for the quality of graduate supervision which has received little attention is the number of students supervised by a supervisor. Formally established limits on the number of graduate students who can be supervised by an individual professor are rare in graduate programs at Canadian universities: only $9.4 \%$ of programs surveyed in Canada have established such limits (Holdaway, Deblois \& Winchester, 1993). Among these, $78 \%$ have established a maximum student-tosupervisor ratio of less than or equal to $6: 1$. An optimum student/staff ratio would be that which facilitates supervision and reasonable time to completion. Optimum student/staff supervision ratios, however, are difficult to set as they will vary according to the professor's academic responsibilities, including the number and level of courses taught, the number of other professorial duties of a research or administrative nature, the organization of the professor's research program, and the level of research of students (master's or doctoral).

Another important resource factor in students' experience of graduate education is gender representativeness (Berg \& Ferber, 1983; Epp, 1994; Hite, 1985). Of immediate relevance to supervision is the existence of gender role models which may be particularly beneficial for female graduate students (National Advisory Board on Science and Technology, 1993). For example, a positive relationship has been found between the number of female faculty and 
the number of female students successfully completing doctorates in the natural sciences (Tidball, 1986). In another study, female graduate students recommended that universities employ more female professors to provide more role models (Epp, 1994). These findings suggest that the number of same gender supervising faculty available for students is another potential benchmark for program quality.

\section{Objectives of the Study}

Given the preceding research base, this study was designed to address four objectives concerning the quality of supervision at a Canadian research university with a history of decentralized administration of graduate programs. The first was to establish the resource base for supervision across disciplines, principally the availability of faculty. The second was to determine which departments had explicit policies and procedures, the nature of the supervision issues addressed by them, and the means by which they were communicated to department members. The third objective was to establish the extent to which various factors, both interpersonal and procedural, were perceived by those responsible for the programs-graduate program directors - as important in graduate student supervision. The fourth objective was to determine the means by which graduate supervision was evaluated in various faculties and departments.

\section{Method}

In 1992, a survey questionnaire was designed in conjunction with the Faculty of Graduate Studies and was sent to all graduate program directors in the faculties offering graduate degrees in the university. The questionnaire consisted of sets of questions on (a) the existence of supervision policies and procedures in the department and how these were communicated, (b) whether there were specified procedures for the assignment of students, financial assistance, etc., and (c) the importance of various factors, for example, knowledge of the research field or of policies and procedures. A 6-point scale was used to rate the factors. (The scale consisted of the following ratings: $0=$ no importance, $1=$ very low importance, $2=$ low importance, $3=$ moderate importance, $4=$ high importance, 5 = very high importance.) Recipients were asked to complete the survey on behalf of their departments or programs, to include a statement of the number of graduate students and faculty who supervise students in the department or program, and to supply documents concerning the policies and procedures for graduate student supervision used in their departments. Comments were invited on the topics addressed in the survey. 
In this university, six faculties consist of departments (Agricultural Science, Arts, Education, Engineering, Health Science and Science). From these faculties, 48 program directors returned questionnaires, accounting for $69 \%$ of the approved master's level graduate programs and $70 \%$ of the approved doctoral programs. The response rates for master's programs ranged from $61 \%$ to $88 \%$, while that for doctoral programs ranged from $60 \%$ to $100 \%$.

To obtain the student/staff ratio, the number of graduate students enrolled as reported by each department was divided by the number of supervisors reported as available. The figure of 6:1 was adopted as a benchmark for purposes of comparison (Holdaway, Deblois \& Winchester, 1993). In addition to frequency data, comments from the program directors' questionnaire forms were used to elucidate findings.

\section{Results and Discussion}

\section{Resource Base}

The student/supervisor ratios for five of the six faculties fell at or below the benchmark figure of 6:1; only Education had a higher ratio (12:1) (Table 1). Almost two-thirds (64\%) of the graduate students were enrolled at the master's level but proportions fluctuated across the faculties, with Education (87\%) the highest, Engineering (67\%) and Agricultural Sciences (62\%) average, and Health Sciences (49\%), Arts (48\%) and Science (45\%) the lowest. One explanation for the variability in the proportion of master's level students is the additional responsibility that some faculties have for professional upgrading. For instance, in the faculty of Education, courses taken for professional upgrading are at the graduate level and lead to a master's degree in education. While the university has adopted a new policy which places greater emphasis on doctoral rather than on master's level degree programs, apparently in at least one faculty this emphasis is moderated by the faculty's decision to remain responsive to the needs of its local professional community. Would this affect the student/supervisor ratio in the need for more or less supervision? Universities have argued that doctoral degrees require more time to complete and hence doctoral supervision should receive more credit. However, from a developmental perspective, one could argue that master's level students, being novices in graduate education, would require more intensive supervision.

Approximately equal numbers of men and women were enrolled in graduate level programs overall (52\% male and $48 \%$ female) (Table 2). Within the master's level programs, there were more women $(56 \%)$ than men $(44 \%)$. At 
Table 1

Number and Ratio of Graduate Students and Supervisors in Programs as Reported in Survey

\begin{tabular}{lccccc}
\hline & \multicolumn{3}{c}{ Students } & & Student-to- \\
\cline { 2 - 4 } Faculty & Master's & PhD & Total & Supervisors & \begin{tabular}{c} 
Staff Ratio \\
\hline Agricultural Science
\end{tabular} \\
\cline { 2 - 5 } Arts & 164 & 99 & 263 & 66 & $4: 1$ \\
Education & 162 & 173 & 335 & 77 & $4: 1$ \\
Engineering & 693 & 108 & 801 & 65 & $12: 1$ \\
Health Science & 468 & 231 & 699 & 125 & $6: 1$ \\
Science & 262 & 276 & 538 & 267 & $2: 1$ \\
\hline Total & 163 & 201 & 364 & 144 & $3: 1$ \\
\hline
\end{tabular}

Table 2

Number and Percentage of Graduate Students by Gender

\begin{tabular}{lrrrrrr}
\hline & \multicolumn{2}{c}{ Master's } & \multicolumn{2}{c}{ PhD } & \multicolumn{2}{c}{ Total } \\
\cline { 2 - 7 } Faculty & Male & Female & Male & Female & Male & Female \\
\hline Agricultural Science & 94 & 70 & 70 & 29 & 164 & 99 \\
& $57 \%$ & $43 \%$ & $71 \%$ & $29 \%$ & $62 \%$ & $38 \%$ \\
Arts & 61 & 101 & 82 & 91 & 143 & 192 \\
& $38 \%$ & $62 \%$ & $47 \%$ & $53 \%$ & $43 \%$ & $57 \%$ \\
Education & 103 & 590 & 37 & 71 & 140 & 661 \\
& $15 \%$ & $85 \%$ & $34 \%$ & $66 \%$ & $17 \%$ & $83 \%$ \\
Engineering & 358 & 110 & 211 & 20 & 569 & 130 \\
& $76 \%$ & $24 \%$ & $91 \%$ & $9 \%$ & $81 \%$ & $19 \%$ \\
Health Science & 119 & 143 & 151 & 125 & 270 & 268 \\
& $45 \%$ & $55 \%$ & $55 \%$ & $45 \%$ & $50 \%$ & $50 \%$ \\
Science & 103 & 60 & 159 & 42 & 262 & 102 \\
& $63 \%$ & $\mathbf{3 7 \%}$ & $\mathbf{7 9 \%}$ & $21 \%$ & $72 \%$ & $28 \%$ \\
\hline Total & $\mathbf{8 3 8}$ & $\mathbf{1 , 0 7 4}$ & $\mathbf{7 1 0}$ & $\mathbf{3 7 8}$ & $\mathbf{1 , 5 4 8}$ & $\mathbf{1 , 4 5 2}$ \\
& $\mathbf{4 4 \%}$ & $\mathbf{5 6 \%}$ & $\mathbf{6 5 \%}$ & $\mathbf{3 5 \%}$ & $\mathbf{5 2 \%}$ & $\mathbf{4 8 \%}$ \\
\hline
\end{tabular}


Table 3

Number and Ratio of Graduate Students and Supervisors by Gender.

\begin{tabular}{|c|c|c|c|c|c|c|}
\hline \multirow[b]{2}{*}{ Faculty } & \multicolumn{2}{|c|}{ Students* } & \multicolumn{2}{|c|}{ Supervisors } & \multicolumn{2}{|c|}{$\begin{array}{c}\text { Student to } \\
\text { Supervisor Ratio }\end{array}$} \\
\hline & Male I & Female & Male & Female & Male & Female \\
\hline Agricultural Science & $\begin{array}{l}164 \\
62 \%\end{array}$ & $\begin{array}{l}99 \\
38 \%\end{array}$ & $\begin{array}{l}58 \\
88 \%\end{array}$ & $\begin{array}{l}8 \\
12 \%\end{array}$ & $3: 1$ & $12: 1$ \\
\hline Arts & $\begin{array}{l}143 \\
43 \%\end{array}$ & $\begin{array}{l}192 \\
57 \%\end{array}$ & $\begin{array}{l}53 \\
69 \%\end{array}$ & $\begin{array}{l}24 \\
31 \%\end{array}$ & $3: 1$ & $8: 1$ \\
\hline Education & $\begin{array}{l}140 \\
17 \%\end{array}$ & $\begin{array}{l}661 \\
\quad 83 \%\end{array}$ & $\begin{array}{l}44 \\
68 \%\end{array}$ & $\begin{array}{l}21 \\
32 \%\end{array}$ & $3: 1$ & $32: 1$ \\
\hline Engineering & $\begin{array}{l}569 \\
\quad 81 \%\end{array}$ & $\begin{array}{l}130 \\
\quad 19 \%\end{array}$ & $\begin{array}{l}116 \\
93 \%\end{array}$ & $\begin{array}{l}9 \\
7 \%\end{array}$ & $5: 1$ & $14: 1$ \\
\hline Health Science & $\begin{array}{l}270 \\
50 \%\end{array}$ & $\begin{array}{l}268 \\
50 \%\end{array}$ & $\begin{array}{l}187 \\
70 \%\end{array}$ & $\begin{array}{l}80 \\
30 \%\end{array}$ & $1: 1$ & $3: 1$ \\
\hline Science & $\begin{array}{l}262 \\
72 \%\end{array}$ & $\begin{array}{l}102 \\
\quad 28 \%\end{array}$ & $\begin{array}{r}132 \\
92 \%\end{array}$ & 12 & $2: 1$ & $9: 1$ \\
\hline Total & $\begin{array}{r}1,548 \\
52 \%\end{array}$ & $\begin{array}{l}1,452 \\
48 \%\end{array}$ & $\begin{array}{l}590 \\
79 \%\end{array}$ & $\begin{array}{r}154 \\
21 \%\end{array}$ & $3: 1$ & $9: 1$ \\
\hline
\end{tabular}

* Master's and PhD students combined

the doctoral level, however, the percentage of women was $35 \%$, closely matching the reported percentages of female doctoral students for Quebec and for Canada (Statistics Canada Data for 1991-92, CAUT Bulletin, 1993). Across faculties, there was wide variation in the ratio of men to women, particularly at the doctoral level. Engineering $(81 \%)$ and Science $(72 \%)$ reported the highest percentage of men, while Education (83\%) reported the highest percentage of women.

In contrast, of the total number of supervisors in graduate programs, $21 \%$ were women and $79 \%$ were men (Table 3 ). This parallels the cross-Canada finding of $19 \%$ female and $81 \%$ male supervisors (Holdaway et al., 1993). In the present study, while the university ratio of male students to male supervisors was $3: 1$, the ratio of female students to female supervisors was $9: 1$. For female graduate students, the availability of potential female supervisors was greatest in health science $(3: 1)$ and least in education (32:1), suggesting relatively limited candidate pools for same sex role models in some faculties. 


\section{Acknowledgment of Supervision}

The specific acknowledgment and rewarding of time devoted by faculty to supervision in workload assignments (e.g., by reduction in number of courses) was reported by very few ( 7 or $15 \%$ ) program directors. When asked to describe how good supervision was recognized, respondents made the following comments:

Good supervision is noted in departmental annual report and merit recommendations.

Workload; Merit presentations.

Not formally. Indirectly, students seem to acknowledge performance by making their choice of supervisor. Internship supervisors are evaluated by students but superior performance would depend on many factors not under control of supervisor.

It represents part of the teaching dossier for supervisors for promotion and tenure considerations.

As seen in final product of student's thesis/work.

By means of intradepartmental scholarship.

These results and comments suggest that current practice is to recognize supervision duties only within the more general framework of evaluation for merit or promotion. Thus, it can be deduced that supervision is not a specifically recognized responsibility measured in workload accounting within most departments.

\section{Department Policies and Procedures}

Most departments or faculties did not have an explicit definition of supervision. Only $36 \%$ of the program directors reported that they distinguished between different forms of supervision such as academic advising, research supervision, and field supervision. In most of those cases, academic advising was seen as separate from supervision and was often, but not always, carried out by individuals other than those supervising a graduate student's research. Responsibility for research supervision could be vested in a supervisor, a committee, or a supervisor and a committee. While most departments (83\%) within the six faculties reported having some form of policies and procedures for graduate student supervision, the extent to which these were in written form varied a great deal from one faculty to another. For example, policies were explicitly stated in as many as $67 \%$ of the departments in Education and Health Sciences and in as few as $10 \%$ in the Faculty of Arts (Table 4).

Overall, the majority of departments (from $40 \%$ to $83 \%$ across faculties) claimed that existing policies and procedures were communicated to all supervisors 
Table 4

Percentage Indicating Existence of Supervision Policies and Procedures in Departments

\begin{tabular}{|c|c|c|c|c|c|c|}
\hline $\begin{array}{l}\text { Supervision Policy } \\
\text { Characteristic }\end{array}$ & $\begin{array}{l}\text { Agr } \\
(7)^{*}\end{array}$ & $\begin{array}{l}\text { Arts } \\
(10)\end{array}$ & $\begin{array}{l}\text { Edu } \\
(6)\end{array}$ & $\begin{array}{l}\text { Eng } \\
(8)\end{array}$ & $\begin{array}{l}\text { Health } \\
(12)\end{array}$ & $\begin{array}{l}\text { Science } \\
(5)\end{array}$ \\
\hline $\begin{array}{l}\text { There are policies and procedures } \\
\text { in the department concerning } \\
\text { graduate student supervision }\end{array}$ & $100 \%$ & $70 \%$ & $83 \%$ & $75 \%$ & $83 \%$ & $100 \%$ \\
\hline $\begin{array}{l}\text { Supervision policies and } \\
\text { procedures are explicitly stated }\end{array}$ & $57 \%$ & $10 \%$ & $67 \%$ & $50 \%$ & $67 \%$ & $60 \%$ \\
\hline $\begin{array}{l}\text { All programs/levels }(\mathrm{MA}, \mathrm{PhD}) \text { use } \\
\text { the same policies or procedures }\end{array}$ & $29 \%$ & $20 \%$ & $33 \%$ & $13 \%$ & $38 \%$ & $80 \%$ \\
\hline $\begin{array}{l}\text { Supervision policies and } \\
\text { procedures are communicated to } \\
\text { all supervisors of graduate students }\end{array}$ & $71 \%$ & $40 \%$ & $83 \%$ & $63 \%$ & $75 \%$ & $60 \%$ \\
\hline $\begin{array}{l}\text { Policies and procedures are } \\
\text { compiled in a written document } \\
\& \text { are available to everyone } \\
\text { in department/faculty }\end{array}$ & $43 \%$ & $30 \%$ & $50 \%$ & $38 \%$ & $67 \%$ & $40 \%$ \\
\hline $\begin{array}{l}\text { Supervision policies and } \\
\text { procedures are discussed in } \\
\text { department meetings }\end{array}$ & $71 \%$ & $50 \%$ & $83 \%$ & $50 \%$ & $50 \%$ & $100 \%$ \\
\hline $\begin{array}{l}\text { The Chair/Dean informs supervisors } \\
\text { of existing department/faculty } \\
\text { policies and procedures }\end{array}$ & $57 \%$ & $50 \%$ & $50 \%$ & $25 \%$ & $25 \%$ & $20 \%$ \\
\hline $\begin{array}{l}\text { Supervisors rely on colleagues to } \\
\text { find out about policies and procedures }\end{array}$ & $29 \%$ & $10 \%$ & $17 \%$ & $13 \%$ & $13 \%$ & $20 \%$ \\
\hline
\end{tabular}

of graduate students and were discussed in department meetings (50\% to $100 \%$ ). Supervisors relied on colleagues to find out about policies and procedures in relatively few departments ( $10 \%$ to $29 \%$ ). As would be expected, it was relatively uncommon for departments to use the same policies or procedures for all programs or levels of graduate study. The Faculty of Science, which also had the highest ratio of doctoral to master's students (55/45), was an exception in that $80 \%$ of its departments used the same policies for both master's and doctoral level students. This raises the issue of consistency of policy across both programs and levels.

In order to gain insight into how extensive the policies were, respondents were asked to indicate whether or not specific policies existed for a variety of supervision issues including the assignment of students to supervisors or to 
research assistantships, and the provision of financial assistance. One respondent's comment describes the limitations of such policies:

These terms would be, for us, more accurately described ... as "provisions", i.e.,. . . "provisions" for financial assistance, etc. These are conventions and mechanisms set by precedent, and there is no written delineation to my knowledge. There are no statutory provisions, but everything is possible.

In summary, there was major variation within faculties in the extent to which policies were explicit or were communicated to supervisors. This would suggest that typically, supervisors have little to guide them in their relationships with their graduate students. Only in the Faculty of Science did all respondents state that supervision policies and procedures were discussed in their departments. Although graduate education is acknowledged to be an important function in each of the six faculties under study, one must question the level of administrative organization brought to bear. In three of the faculties, according to the directors of the graduate programs, discussion of issues pertaining to graduate supervision policies and procedures took place in only half of their respective departments.

The aspect of supervision for which policies and procedures were most likely to exist was the process of assigning students to supervisors (Table 5). All programs responding from the Faculty of Agricultural Sciences reported policies and procedures for student assignment, as did seven of eight Engineering programs. Policies for assigning workplaces to students and for setting up thesis committees also existed in the majority of departments. However, programs in Arts were less likely to have policies for assigning workplaces.

There was wide variation in the extent to which departments had policies and procedures for the assignment of graduate students to either research or teaching assistantships but policies were more likely to exist for the latter. The greater prevalence of policies pertaining to teaching assistantships might reflect differences in funding sources: operating funds support teaching assistantships while research grants support research assistantships. The training of graduate students to assume teaching responsibilities has increased in importance in universities in the last decade and the relationship of this training to graduate student research and supervision has become part of the debate about the definition of scholarship in higher education (see Diamond \& Adam, 1993). Whether these are complementary or reciprocal activities remains to be established, but in terms of student development, they are both concerned with the socialization of graduate students into the discipline. Assistantships may be viewed as forms 
Table 5

Percentage Indicating Existence of Policies and Procedures for Specific Supervision Issues Within Departments

\begin{tabular}{|c|c|c|c|c|c|c|}
\hline $\begin{array}{l}\text { Supervision Policy } \\
\text { Issue }\end{array}$ & $\begin{array}{l}\mathrm{Agr} \\
(7)^{*}\end{array}$ & $\begin{array}{l}\text { Arts } \\
(10)\end{array}$ & $\begin{array}{l}\text { Edu } \\
(6)\end{array}$ & $\begin{array}{l}\text { Eng } \\
(8)\end{array}$ & $\begin{array}{l}\text { Health } \\
(12)\end{array}$ & $\begin{array}{l}\text { Science } \\
\text { (5) }\end{array}$ \\
\hline Assignment of student to supervisor & $100 \%$ & $60 \%$ & $83 \%$ & $88 \%$ & $83 \%$ & $80 \%$ \\
\hline Assignment of workplace to student & $57 \%$ & $40 \%$ & $67 \%$ & $100 \%$ & $58 \%$ & $100 \%$ \\
\hline Assignment of thesis committee & $43 \%$ & $60 \%$ & $67 \%$ & $63 \%$ & $67 \%$ & $80 \%$ \\
\hline $\begin{array}{l}\text { Assignment of graduate students to } \\
\text { research assistantship positions }\end{array}$ & $14 \%$ & $40 \%$ & $17 \%$ & $63 \%$ & $25 \%$ & $80 \%$ \\
\hline $\begin{array}{l}\text { Assignment of graduate students to } \\
\text { teaching assistantship positions }\end{array}$ & $29 \%$ & $80 \%$ & $67 \%$ & $75 \%$ & $38 \%$ & $100 \%$ \\
\hline $\begin{array}{l}\text { Collaboration between student } \\
\text { and supervisor on papers }\end{array}$ & $29 \%$ & $20 \%$ & $33 \%$ & $13 \%$ & $38 \%$ & $40 \%$ \\
\hline $\begin{array}{l}\text { Financial assistance for } \\
\text { collecting thesis related data }\end{array}$ & $14 \%$ & $0 \%$ & $0 \%$ & $0 \%$ & $26 \%$ & $100 \%$ \\
\hline $\begin{array}{l}\text { Financial assistance for paper presenta- } \\
\text { tions at professional conferences }\end{array}$ & $14 \%$ & $40 \%$ & $33 \%$ & $25 \%$ & $26 \%$ & $60 \%$ \\
\hline $\begin{array}{l}\text { Inclusion of graduate students in policy } \\
\text { decisions concerning supervision }\end{array}$ & $29 \%$ & $20 \%$ & $50 \%$ & $25 \%$ & $50 \%$ & $100 \%$ \\
\hline
\end{tabular}

* Number of questionnaires returned

of financial support, however, rather than as intentional educational components of the graduate curriculum. In this study, financial support for research assistantships and for professional development activities such as conference presentations was provided by half as many departments as provided funding for teaching assistantships.

The issues for which policies and procedures were least likely to exist were collaboration between student and supervisor on papers and financial assistance for collecting thesis data. Overall, departments in the Faculty of Science were most likely to have policies and procedures for dealing with specific supervision issues. While the differences across faculties may accurately reflect priorities and perhaps research funding in the faculties, they suggest a lack of coherence in the university. 


\section{Perceived Importance of Factors affecting Graduate Supervision}

Program directors noted some difficulty in rating the importance of various factors affecting graduate supervision. Some stated that the relative importance of the factors would vary depending on the stakeholder group whose perspective was being assessed. Others noted that trying to differentiate among elements of graduate supervision was not easy as all the factors were very important. Some suggested that graduate supervision was usually unstructured.

The most important factors overall were knowledge of the research field and availability of the supervisor (mean ratings of 4.4 and 4.3 respectively, Table 6). These ratings closely match the research literature (Moses, 1985; Powles, 1993). While there was considerable variation among faculties in the perceived importance of many of the factors, a number of conclusions can be drawn from the overall results. First, individual supervisors play a much more important role in graduate student supervision than committees. Second, in three of the four science-based faculties (Agricultural Science, Engineering, and Science), knowledge of the research field was seen as the paramount requirement of a supervisor; in contrast, among non-science-based faculties, responsiveness to students (availability, promptness in providing feedback, sensitivity) was rated as more important. Third, in spite of increasing concern in universities over the time taken to graduate, this is not viewed as an overriding factor in supervision: mean ratings of importance across faculties ranged from 3.5 to 4.0 with an overall mean of 3.8. Finally, in spite of the high importance accorded the supervisor's knowledge of the research field by all faculties, coherence of thesis research with the supervisor's research tended to be of moderate importance: only Science departments had a mean above 4.0 (4.2).

\section{Evaluation of the Supervision Process}

Relatively few departments (14 or $29 \%$ ) reported that they had a mechanism in place for evaluating the process of graduate student supervision. Respondents from the departments which evaluate supervision were asked to describe the criteria used in conducting such evaluations. Their responses dealt with both criteria and procedures and included the following:

No formal criteria.

Student/prof ratio; areas of research; availability of faculty resources.

Productivity; student complaints.

Amount of time students take to complete the program (i.e., efficiency); quality of theses submitted; comments of external examiners.

Reliability; timely completion of theses; availability. 
Table 6

Importance ${ }^{1}$ of Various Factors in Graduate Supervision

\begin{tabular}{|c|c|c|c|c|c|c|c|}
\hline \multirow[b]{2}{*}{ Factor } & \multirow[b]{2}{*}{$\begin{array}{l}\text { Overall } \\
\text { Average }\end{array}$} & \multicolumn{6}{|c|}{ Faculty Averages } \\
\hline & & $\begin{array}{l}\text { Agr } \\
(7)^{*}\end{array}$ & $\begin{array}{l}\text { Arts } \\
(10)\end{array}$ & $\begin{array}{l}\text { Edu } \\
(6)\end{array}$ & $\begin{array}{l}\text { Eng } \\
(8)\end{array}$ & $\begin{array}{l}\text { Health } \\
(12)\end{array}$ & $\begin{array}{l}\text { Science } \\
\quad(5)\end{array}$ \\
\hline Knowledge of the research field & 4.4 & 4.3 & 4.3 & 4.4 & 4.6 & 4.1 & 5.0 \\
\hline Availability of supervisor & 4.3 & 4.2 & 4.4 & 4.6 & 4.0 & 4.3 & 4.4 \\
\hline $\begin{array}{l}\text { Promptness in providing feedback } \\
\text { to student on thesis related work }\end{array}$ & k 4.1 & 4.0 & 4.0 & 4.3 & 4.3 & 4.2 & 4.0 \\
\hline Sensitivity to student problems & 4.0 & 3.5 & 4.0 & 4.2 & 3.6 & 4.2 & 4.2 \\
\hline Academic advising & 3.8 & 3.5 & 3.9 & 4.2 & 3.9 & 3.9 & 3.6 \\
\hline $\begin{array}{l}\text { Completion of graduate studies } \\
\text { within stated period }\end{array}$ & 3.8 & 3.5 & 4.0 & 3.6 & 3.9 & 3.6 & 4.0 \\
\hline $\begin{array}{l}\text { Frequency of meetings } \\
\text { with students }\end{array}$ & 3.7 & 3.5 & 3.5 & 4.0 & 3.3 & 4.0 & 4.2 \\
\hline $\begin{array}{l}\text { Time period within which } \\
\text { research proposal is submitted }\end{array}$ & 3.7 & 3.8 & 3.2 & 3.0 & 3.7 & 4.2 & 3.6 \\
\hline $\begin{array}{l}\text { Knowledge of policies and proce- } \\
\text { dures (e.g., course requirements } \\
\text { and registration procedures) }\end{array}$ & 3.5 & 3.2 & 4.0 & 4.0 & 2.4 & 3.8 & 3.4 \\
\hline $\begin{array}{l}\text { Coherence of thesis research topic } \\
\text { with supervisor's research }\end{array}$ & 3.4 & 3.7 & 2.5 & 3.3 & 3.4 & 3.8 & 4.2 \\
\hline $\begin{array}{l}\text { Time period within which formal } \\
\text { supervisory committee is formed }\end{array}$ & d 3.3 & 3.7 & 3.8 & 2.0 & 2.7 & 3.8 & 2.6 \\
\hline $\begin{array}{l}\text { Assistance in preparing } \\
\text { fellowship proposals }\end{array}$ & 3.1 & 2.7 & 3.4 & 3.3 & 2.3 & 3.7 & 3.0 \\
\hline $\begin{array}{l}\text { Assistance in preparing research } \\
\text { grant proposals }\end{array}$ & 3.0 & 2.3 & 3.1 & 4.0 & 2.7 & 3.3 & 3.0 \\
\hline $\begin{array}{l}\text { Frequency with which } \\
\text { supervisory committee meets }\end{array}$ & 2.9 & 3.0 & 2.7 & 2.3 & 2.3 & 3.6 & 2.6 \\
\hline
\end{tabular}

1 The scale consisted of the following ratings: $0=$ no importance, $1=$ very low importance, $2=$ low importance, $3=$ moderate importance, $4=$ high importance, $5=$ very high importance.

* Number of questionnaires returned 
Time to complete theses; promptness to follow progress report guidelines.

Number of students, their satisfaction, papers published, awards obtained.

Carried out informally with students and in discussion with faculty colleagues.

Research performance; oral presentation of data; performance in courses.

At time of tenure review, effectiveness of grad student supervision is one criterion - judged by output, success in completion, etc.

Biennial reports signed by committee and student, submitted to Graduate Affairs Committee.

The comments suggest that evaluation of supervision is global, using criteria which are based on cumulative outcomes (e.g., number of students graduated, number of papers published or awards received by students, or quality of theses submitted). Considering the importance accorded factors such as the availability of supervisors, sensitivity to student problems, and academic advising, as well as the importance of student ratings of teaching at the undergraduate level, little emphasis is placed on feedback from students on the process of supervision. Where student input is mentioned, it takes the form of student complaints or informal conversations, although the last comment refers to biennial reports as recommended in university policy statements.

Twenty program directors $(42 \%)$ reported that supervisors are required to prepare an annual written assessment of student progress. The practice was most common in programs in the Health Science and Science faculties. Providing a copy of the annual assessment to the student concerned was slightly less common (35\% of departments) and also occurred most frequently within departments of the same two faculties. With the exception of those faculties, practice is at odds with stated policy recommendations concerning the assessment of students.

\section{Discussion}

If the major purpose of graduate student supervision at both master's and doctoral levels, regardless of academic discipline, is to facilitate student progress to degree completion in a timely and educationally sound fashion, it is best characterized by the diversity of forms it takes across programs. The results of this study suggest that although university-wide policies and guidelines are in place, departments and faculties have interpreted them in different and sometimes limited ways. 
The number of supervisors appeared to be adequate in five of six faculties in relation to the number of students. The limited number of female supervisors in some disciplines means that female graduate students have relatively limited opportunity to work with female supervisors and thus encounter fewer role models than their male peers. More problematic, however, is the fact that supervision is not specifically acknowledged in workload assignments, nor is it evaluated systematically. This is tantamount to according supervision a lower priority than other responsibilities in the department, when it may be one of the most important in terms of the development of the field and the training of future specialists.

There is very little formal organization within the university to aid graduate student supervisors in carrying out their responsibilities. One example of this state of disorganization is the ambiguity in the definition of graduate student supervision and hence, in the delineation of corresponding responsibilities. The literature provides a number of components of supervision which can be grouped under three headings: knowledge of policies and procedures, availability, and advising skills (Pascarella \& Terenzini, 1980; Powles, 1988; Seldin 1980, 1984; Tromblay, 1984; Worthington \& Roehlke, 1979). Knowledge of policies and procedures includes knowledge of: curricular requirements and course offerings, course requirements and registration procedures, institutional policies, research grants, and requirements for graduation. Availability supposes that supervisors have dedicated specific time for student contact. According to the literature, advising skills include the ability to be explicit about the expectations of students and to clarify students' expectations, to advise on career choices, to offer alternative suggestions related to course selection and thesis work while leaving the final judgment to the student, and to offer students constructive feedback on performance. Advising may also include offering helpful counsel in solving academic problems and non-academic problems such as health, language, or financial difficulties, and balancing study and employment. These skills go far beyond the formal expectations of supervision as stated in university policy.

The results of this study indicate that there is great variation in the extent to which departments have adopted policies and procedures for graduate student supervision, the manner in which and extent to which policies and procedures are communicated to supervisors and graduate students, and the importance accorded a variety of factors (e.g., supervisor's knowledge of research field, time to degree completion, sensitivity to student problems) which contribute to this process. The diversity in the practice of graduate student supervision 
between disciplines is to some extent explained by having decentralized faculties. Disciplinary differences also lead to diversity in supervision practice: disciplines offer varying degrees of structure in programs since they define the advancement of knowledge in different ways and hence have different views about what the learning task for their students should be. Diversity in supervision practice may be a result of the absence of comprehensive and commonly accepted conceptualizations of graduate student supervision and how supervision relates to the broader domain of graduate education.

In order to set policies and procedures for graduate student supervision, universities need to find ways by which they can ensure that graduate student supervision is consistently being carried out according to high standards across programs, while ensuring that faculties and departments have the flexibility to modify the form that supervision takes in order to accommodate the educational requirements of particular disciplines. Thus, much of the effort involved in enhancing the quality of graduate student supervision must be made at the faculty and department level. It follows that if the quality of supervision in individual departments is to be enhanced, those most directly affected-supervisors and their graduate students-should know the policies for graduate student supervision. It then becomes incumbent upon faculties and departments to determine their current policies, procedures and practices for graduate student supervision, and to ensure that they facilitate graduate education and are communicated to both supervisors and graduate students. Of major importance is establishing the priority given to supervision in the department and how it is rewarded, so that there is common understanding and appreciation of its role. Departments might also consider what types of professional and academic skills and attitudes faculty as a whole and supervisors in particular should model for their graduate students, and what activities department members might engage in with graduate students as a means of furthering professional socialization.

In human service organizations, the impetus for providing assistance results from delineation of responsibilities. Supervision responsibilities can be specified at four levels in a university: faculties of graduate studies, departments, supervisors, and students. The department, representing the discipline, has the major responsibility, including publishing information about the department and the research interests and publications of faculty, providing information about what is expected of graduate students, providing information about facilities and financial assistance available in the department, offering pre-enrollment advising, providing guidelines for regular meetings between student and supervisor, and informing supervisors of curriculum and policy changes in the university, 
faculty, and department. Department planning activities should ensure that in the areas of specialization offered by the department, more than one faculty member is available, that high standards of research are maintained, that a limit to the ratio of students to supervisor is set, and that procedures are in place for accountability regarding supervision and implementing change if results are not satisfactory. It should also be the department's responsibility to ensure that students are made aware of the expected timelines, and to provide workplaces for students and opportunities for contact between students and faculty. Acknowledging and rewarding time devoted by faculty to supervision as well as membership in doctoral committees is fundamental to ensuring quality supervision.

The responsibilities of the supervisor would include being knowledgeable about relevant policies, particularly issues such as comprehensive examinations, doctoral committee formation, committee meetings and the oral defence, if there is one. Supervisors could be expected to provide graduate students with research assistantships when possible, to provide guidance in the phases of the development of the thesis, to meet regularly with the student (for example, once a week for one hour), to provide prompt feedback when work is handed in (within one week), and to provide feedback about the research area, quality of work, and value of the research. Areas of joint responsibility between supervisors and departments might include clarifying expectations regarding collaborative work, authorship, publication, and conference presentations, maintaining a dossier on student progress (up-dated at least every semester), knowing graduation deadlines, and introducing the student to professional organizations and encouraging participation thereafter (for example, providing funding for initial participation at a professional meeting).

The responsibilities of students would include understanding the scope of master's and doctoral work such as the number of years to be devoted to fulltime study, knowledge of research methods necessary to carry out studies, and the expectations of the supervisor regarding every aspect of the research (e.g., scope of the research program, role of the student as a research team member, team publications/ presentations, financial support versus sharing of ideas). Students should expect to work within deadlines, to communicate directly with the supervisor (particularly if misunderstandings arise), and to submit a comprehensive annual progress report to the supervisor and the department.

At a more general level, faculties of graduate studies should be developing a comprehensive description of graduate student supervision. Such a description would contribute significantly to ensuring that a common terminology exists for subsequent discussions of graduate student supervision. Among the issues 
which appear to need further examination are the similarities and differences in the types of graduate student supervision required in different academic disciplines and in the supervision of master's and doctoral students.

Evidently the process of supervision is complex. Given its importance in the development of knowledge and more specifically of fields of study, it is also critical that universities establish policies and procedures at several levels of the institution to enable professors and students to actively support that development.

\section{References}

Ballard. B., \& Clanchy, J. (1993). Supervising students from overseas. In D. J. Cullen (Ed.), Quality in PhD education (pp. 61-73). Canberra: Australian National University.

Bargar, R.R., \& Mayo-Chamberlain, J. (1983). Advisor and advisee issues in doctoral education. Journal of Higher Education, 54(4), 407-432.

Beeler, K.D. (1991). Graduate student adjustment to academic life: A four-stage framework. NASPA Journal, 28(4), 163-171.

Berg, H.M., \& Ferber, M.A. (1983). Men and women graduate students: Who succeeds and why? Journal of Higher Education, 54(6), 629-648.

Bowen, W.G., \& Rudenstine, N.L. (1992). In pursuit of the PhD. Princeton, NJ: Princeton University.

Council of Graduate Schools. (1990). Research student and supervisor. Washington, DC: Author.

Diamond, R.M., \& Adam, B.E. (1993). Recognizing faculty work: Reward systems for the Year 2000. New Directions for Higher Education, (81). San Francisco: Jossey-Bass.

Epp, J.R. (1994). Women's perceptions of graduate level educational administration programs. Canadian Journal of Higher Education, 24(2), 43-67.

Friedman, N. (1987). Mentors and supervisors. New York: Institute of International Education. (ERIC Document Reproduction Service, ED 295 541).

Graduate Faculty Council. (1986). Time to Complete Graduate Studies. Montreal: McGill University.

Hite, L.M. (1985). Female doctoral students: Their perceptions and concerns. Journal of College Student Personnel, 26(1), 18-22.

Holdaway, E.A. (1991, June). Organization and administration of graduate studies in Canadian universities. Paper presented at the annual conference of the Canadian Society for the Study of Higher Education, Kingston.

Holdaway, E.A., Winchester, I.S., \& Deblois, C. (1993, June). Organizational issues in graduate studies. Paper presented at the annual conference of the Canadian Society for the Study of Higher Education, Ottawa.

Holdaway, E.A., Winchester, I.S., \& Deblois, C. (1994, June). Opinions of supervisors of graduate students about supervisory practice. Paper presented at the annual conference of the Canadian Society for the Study of Higher Education, Calgary.

Katz, J., \& Hartnett, R.T. (Eds.) (1976). Scholars in the making: The development of graduate and professional students. Cambridge, MA: Ballinger.

McGill University. (1990), Graduate Admissions. Montreal: Author. 
McGill University. (May, 1991). Report of the Task Force on Priorities. Montreal: Author. McGill University. (1993). A Handbook on Students' Rights and Responsibilities. Montreal: Author.

Moses, I. (1985). Supervising postgraduates. Sydney, Australia: Higher Education Research and Development Society of Australasia, University of New South Wales.

Moses, I. (1992). Good supervisory practice. In I. Moses (Ed.), Research training and supervision (pp. 11-15). Canberra: Australian Research Council.

National Advisory Board on Science and Technology (1993). Winning with women in trades, technology, science, and engineering. Ottawa: Author.

Pascarella, E., \& Terenzini, P. (1980). Predicting freshman persistence and voluntary dropout decisions from a theoretical model. Journal of Higher Education, 51, 60-75.

Powles, M. (1988). Know your PhD students and how to help them. Melbourne, Australia: Centre for the Study of Higher Education, University of Melbourne.

Powles, M. (1993). Staff development for PhD supervision. In D. J. Cullen (Ed.), Quality in PhD education (pp. 75-84). Canberra: Australian National University.

Salmon, P. (1992). Achieving a PhD-Ten students' experience. Stoke-on-Trent, England: Trentham Books.

Seldin, P. (1980). Successful faculty evaluation programs. Crugers, NY: Coventry.

Seldin, P. (April, 1984). Faculty evaluation: Surveying policy and practices. Change, 16, 28-33.

Sheridan, P.M., \& Pyke, S.W. (1994). Predictors of time to completion of graduate degrees. Canadian Journal of Higher Education, 24(2), 68-88.

Smith, S.L. (1991). Report of the Commission of Inquiry on Canadian University Education. Ottawa: Association of Universities and Colleges of Canada.

Tidball, M. (1986). Baccalaureate origins of recent natural science doctorates. Journal of Higher Education, 57, 606-620.

Tinto, V. (1993). Leaving college: Rethinking the causes and cures of student attrition (2nd ed.). Chicago: University of Chicago Press.

Tromblay, T. (1984). The effectiveness of faculty advisors: Theory and assessment. Unpublished doctoral dissertation, McGill University, Montreal.

Tuckman, H.P. (1991) Measuring, understanding and doing something about the rise in doctorate completion time. In J.C. Smart (Ed.), Higher education: Handbook of theory and research, Vol. VII (pp. 223-260). New York: Agathon Press.

Winston, R.B., Jr., \& Polkosnik, M.C. (1984). Advising graduate and professional school students. In R.B. Winston, Jr., T.K. Miller, S.C. Ender, \& T.J. Grites (Eds.), Developmental academic advising: Addressing students' educational, career, and personal needs (pp. 287-314). San Francisco: Jossey-Bass.

Worthington, E., \& Roehlke, H. (1979). Effective supervision as perceived by beginning counselors-in-training. Journal of Counselling Psychology, 26(1), 64-73. 